$\begin{array}{cc}\text { Tür Coğrafya Dergisi } & \text { Turkish Geographical Review } \\ \text { Basılı ISSN 1302-5856 } & \text { www.tcd.org.tr }\end{array}$

\title{
Mağaraların peynir olgunlaştırmada kullanımı, bir örnek araştırma: Peynirini Mağarası, Derbent/ Konya
}

\author{
Using caves in cheese ripening, a case study: Peynirini Cave, Derbent/ Konya
}

\author{
Ayşe Dağlı *a (1) Durmuş Sert ${ }^{b}$ (1) Ali Uzun ${ }^{c}$ \\ ${ }^{a}$ Ondokuz Mayıs Üniversitesi, Sosyal Bilimler Enstitüsü, Coğrafya Anabilim Dalı, Samsun \\ ${ }^{b}$ Necmettin Erbakan Üniversitesi, Mühendislik ve Mimarlık Fak., Gıda Müh. Bölümü, Konya, Türkiye \\ ' Ondokuz Mayıs Üniversitesi, Fen Edebiyat Fakültesi, Coğrafya Bölümü, Samsun, Türkiye \\ ORCID: A.D. 0000-0003-3312-6235; D.S. 0000-0002-4073-0468; A.U. 0000-0003-3854-2780
}

\section{BILGI / INFO}

Geliş/Received: 11.10 .2020

Kabul/Accepted: 02.12.2020

\section{Anahtar Kelimeler:}

Tulum peyniri

Peynirini Mağarası

Mağara iklimi

Derbent

Konya

\section{Keywords:}

Tulum cheese

Peynirini Cave

Cave climate

Konya

Derbent

*Sorumlu yazar/Corresponding author:

(A.Dağ|ı) aysedagli.tr@gmail.com

DOI: $10.17211 /$ tcd.809065

\section{Atf/Citation}

Dağlı, A., Sert, D. ve Uzun, A. (2020). Mağaraların peynir olgunlaştırmada kullanımı, bir örnek araştırma: Peynirini Mağarası, Derbent/ Konya. Türk Coğrafya Dergisi (75), 131-138.

DOI: $10.17211 /$ tcd. 809065

\section{ÖZ / ABSTRACT}

Türkiye, elverişli iklim koşulları ve yaygın karstik kayaçlar nedeniyle çok zengin karstik şekillere sahiptir. Bu şekillerden biri de derinlik karstına ait mağaralardır. Mağaralar, ilk çağlardan beri barınma, arınma, su temini, madencilik, turizm, sağlık, depolama, tarımsal üretim ve benzeri amaçlarla kullanılmıştır. Mağaraların tarımsal amaçlı kullanımlarından biri de tulum peyniri olgunlaştırılmasıdır. Bu çalışmada, tulum peyniri olgunlaştırılmasında kullanılan Peynirini Mağarası ve burada olgunlaştırılan peynirlerin bazı özellikleri çok yönlü olarak incelenmiştir. Peynirini Mağarası, İç Anadolu Bölgesi'nin Konya Bölümü’nde ve Konya ilinin Derbent ilçesine bağlı Mülayim Mahallesi’nde yer almaktadır. Bu çalışma hazırlanırken mağaranın iklimi ile ilgili ölçümler yapılmış; mağara damlama suyundan, mağara yüzeyinden ve depolanan peynirlerden alınan örneklerin mikrobiyolojik analizleri yapılmıştır. Ayrıca, peynirlerin koku ve tat özelliklerinin değerlendirilmesi amacıyla 100 kişiye duyusal anket uygulanmıştır. Peynirini Mağarasının toplam galeri uzunluğu 187 m’dir. Özel donanımsız girilebilen ilk bölümü iki salondan oluşmaktadır. Peynirlerin depolandığı büyük salona "Peynir Salonu" diğerine ise "Alt Salon" denilmektedir. Alt salon damlataşı şekilleri bakımından zengindir. Mağara havası, "Giriş" kısmı hariç dış atmosfer şartlarından fazla etkilenmez. Yıl boyu sıcaklık 6-7 ${ }^{\circ} \mathrm{C}$ civarında seyretmektedir. Mağara havası yüksek nem doygunluğuna sahiptir (\%99,6-100). Mağarada olgunlaştırılan peynirlerle mağara ortamındaki Toplam Aerobik Mezofilik, Toplam Maya - Küf, Koliform ve Staphylococcus bakterileri birbirini pozitif yönde etkilemektedir. Mağarada üretilen peynirlerde Staphylococcus sayısı 0.85 log kob/g olarak ölçülmüştür. Bu değer sağlık eşik değeri üst sınırının $\left(<10^{3}\right)$ altında ve kabul edilebilir sınırlar içindedir. Uygulanan duyusal anket sonuçlarına göre, mağarada olgunlaştırılmış tulum peyniri, taze peynire göre daha çok beğenilmiştir. Peynirini Mağarası'ndan sürdürülebilir şekilde yararlanmak için, depolanma şartlarının iyileştirilmesi, olgunlaştırılan peynirlere coğrafi işaret alınması ve daha fazla tanıtım yapılması önerilmektedir.

Turkey has very rich karstic shapes due to the favorable climatic conditions and widespread karstic rocks. One of these shapes is also caves belonging to the depth karst. Caves have used for shelter, worship, water supply, mining, tourism, health, storage, agricultural production and similar purposes since ancient times. One of the agricultural usages of the caves is the ripening of Tulum (leather bottle) cheese. In this study, Peynirini Cave used in the ripening of Tulum cheese and some properties of cheeses produced there were examined in a versatile way. Peynirini Cave is located in Konya part of Central Anatolia Region and in Mülayim village of Derbent district of Konya province. While preparing this study, measurements were made regarding the climate of the cave; and were made microbiological analysis the samples taken from the cave water, cave surface and stored cheese. In addition, sensory questionnaires were applied to 100 people in order to evaluate the odor and taste properties of cheeses. The total gallery length of Peynirini Cave is $187 \mathrm{~m}$. The first section, which can be entered without special equipment, consists of two halls. The large hall where cheeses are stored is called the "Cheese Hall" and the other is called the "Lower Hall". The lower hall is rich in speleothems. The cave air is not affected much by the external atmospheric conditions except the "Entrance" section. The temperature is around $6-7^{\circ} \mathrm{C}$ throughout the year. Cave air has high humidity saturation (99.6-100\%). Total Aerobic Mesophilic, Total Yeast - Mold, Coliform and Staphylococcus bacteria in the cave environment with the cheeses ripened in the cave affect each other positively. Staphylococcus count was measured as 0.85 $\log \mathrm{kob} / \mathrm{g}$ in cheeses produced in the cave. This value is below the upper limit of health threshold $\left(<10^{3}\right)$ and is within acceptable limits. According to the results of the sensory questionnaire applied, tulum cheese ripened in the cave was appreciated more than fresh cheese. In order to benefit from the Cheese Cave in a sustainable way, it is recommended to improve the storage conditions, obtain geographical indications for the cheeses ripened and make more promotion. 
Extended Abstract Introduction

Turkey has very rich karstic shapes due to the favorable climatic conditions and widespread karstic rocks. One of these shapes is also caves belonging to the depth karst. Caves have used for shelter, worship, water supply, mining, tourism, health, storage, agricultural production and similar purposes since ancient times. One of the agricultural usages of the caves is the production of Tulum (leather bottle) cheese. Cheese production is one of the oldest methods of food preservation and it is accepted that it started in Mesopotamia around 8 ka BP (Stark, 2007). Caves generally have a cool, humid and stable climate year-round. For this reason, they have been used for the maturation and storage of cheeses with microbiological activities for centuries. For instance, some cheese varieties well known in Europe such as Roquefort (France) and Gorgonzola (Italy) are produced in caves. In our country also, there are varieties of cheese matured in caves. Among these cheeses "Peynirini Tulum Cheese" which studied in this paper and "Karaman Divle Tulum Cheese" have come to the fore in recent years. In Turkish, the word "in" is used synonymously with cave. The cave investigated in this study and used in cheese production is called Cheese Cave (Peynirini) in the region. This definition became name for the cave over time and the cave was started to be called as "Peynirini Cave". During the literature studies, no detailed study was found on cheese production in Peynirini Cave. However, two unpublished research reports on the geological and speleological features of the cave (Güngör et al.2018, Nazik et al.2005), and a statement on the use of the cave by the local people was prepared and its abstract was published (Sarı and Aydemir 2017). This study was prepared to examine Peynirini Cave Tulum cheeses and some cave features that affect cheese production. The cave is located in the Central Anatolia Region and in the Mülayim village of Derbent district of Konya (Figure 1). The coordinates of the cave entrance are $37^{\circ} 59^{\prime} 7^{\prime \prime} \mathrm{N}$ and $32^{\circ} 5^{\prime} 5^{\prime \prime} \mathrm{E}$, and its altitude is $1819 \mathrm{~m}$.

\section{Data and Method}

While preparing this study, measurements were made regarding the climate of the cave; and were made microbiological analysis the samples taken from the cave water, cave surface and stored cheese. In addition, sensory questionnaires were applied to 100 people in order to evaluate the odor and taste properties of cheeses. Within the scope of field studies, temperature and humidity recorders were used for the measurements of the cave climate. The devices were placed to outside the cave, cave entrance, Cheese Hall and Lower Hall. The measurements were made simultaneously and according to 24-hours recording system. The measurements started at the beginning of the cheese ripening period and lasted for 1 year (01.06.2019 - 01.05.2020). Measurement results were analyzed using SigmaPlot 12.0 software. Within the scope of laboratory studies, Plate Count Agar (PCA) for Total Aerobic Mesophilic Bacteria (TAMB) count in the samples, Potatoes Dextrose Agar (PDA) for yeast mold count, Violet Red Bile Agar (VRBA) for Coliform bacteria counting and Baird Parker Agar (BPA) methods were used for Staphylococcus bacteria count. In addition, the effect of bacterial number in cave drip water and cave walls on tulum cheese bacterial number were investigated by Simple Linear Regression and Pearson Product Moment Correlation Coefficient analyzes in the SPSS 18.0 statistical program. In addition, in order to evaluate the odor and taste properties of cheeses matured in the cave and unripe cheeses, sensory questionnaire was applied to 100 people. The panelist group was randomly selected from the participants over the age of 25 living in Selçuklu and Karatay Districts of Konya Province.

\section{Findings}

Peynirini Cave was developed within the Triassic aged limestones, which are widely distributed in the region. The cave was developed in an oblique direction and has a total length $187 \mathrm{~m}$. The first section, which can be entered without special equipment, consists of two halls. The large hall where cheeses are stored is called the "Cheese Hall" and the other is called the "Lower Hall". The lower hall is rich in speleothems. The cave air is not affected much by the external atmospheric conditions except the "Entrance" section. The average annual temperature of the cave is $6^{\circ} \mathrm{C}$ and the annual average humidity is $99.6 \%$. The steady trend of the temperature and humidity levels of the cave throughout the year is show suitable for the maturation of Tulum cheese.

Tulum cheeses are filled in leather bottles called "tulum" or "tuluk" made of animal skins, and they are stored in caves for 5-6 months (between June and November) to gain taste and aroma. For this aim, plastic drums are also used in the recent years. The cave is rented by the Municipality of Derbent on an auction basis and the manager has a guard in the cave. Cheeses matured in the cave are charged per kilogram. The amount of cheeses put into the cave varies from year to year. A significant portion of the matured cheeses are consumed by the producer families. However, surplus products are sold in local neighborhood markets, contributes to the family budget. In recent years, the reputation of these cheeses has increased, from the surrounding provinces and districts has also started to be demands.

\section{Results and Conclusions}

As a result of the correlation analysis, with the microbial properties of Tulum cheese; a high positive relationship between microbial properties of the cave surface and it was found a very high positive between microbial properties of the cave drip water. Therefore, it was concluded that the microbiological characteristics of the cave environment had an effect on the Tulum cheeses. The count of Staphylococcus in the cheese produced in the cave was found $0.85 \mathrm{log} \mathrm{CFU} / \mathrm{g}$. This value is below the upper limit of health threshold $\left(<10^{3}\right)$ and is within acceptable limits according to the Turkish Food Codex Microbiological Criteria Notification (2011). According to the results of the sensory questionnaire applied, Tulum cheese matured in the cave was appreciated more than fresh cheese. In order to benefit from the Cheese Cave in a sustainable way, it is recommended to improve the storage conditions, obtain geographical indications for the cheeses produced and make more promotion. 


\section{Giriş}

Türkiye, uygun iklim ve kayaç özellikleri nedeniyle karstik şekillerin yaygın olduğu bir ülkedir. Bu şekillerden biri de derinlik karstına ait mağaralardır. Mağaralar, ilk çağlardan beri barınma, arınma, depolama ve su temini gibi çeşitli amaçlarla kullanılmıştır (Gillieson, 1998; Uzun, 1995). Günümüzde ise daha çok tarımsal üretim, depolama, sağlık, spor, turizm ve bilimsel araştırma gibi amaçlarla kullanılmaktadır (Ege, 2017; Uzun ve Zeybek, 1996; Zeybek, 2001).

Türkçede "in" kelimesi mağara anlamında kullanılmaktadır. Bu çalışmada incelenen ve peynir olgunlaştırmada kullanılan mağaraya da peynir üretilen yer anlamında peynir ini denilmekteydi. Bu tanımlama zamanla mağaraya ad olmuş ve mağara "Peynirini Mağarası" olarak anılmaya başlamıştır. Bu çalışma Peynirini Mağarası'nın peynir üretimini etkileyen bazı özelliklerini ve burada olgunlaştrılan peynirlerin bazı duyusal karakterlerini incelenmek amacıyla hazırlanmıştır. Mağara, iç Anadolu Bölgesi'nde ve Konya ilinin Derbent ilçesine bağlı Mülayim Mahallesi'nde yer almaktadır (Şekil 1). Mağara girişinin rakımı $1819 \mathrm{~m}$ ve koordinatları $37^{\circ} 59^{\prime} 7^{\prime \prime} \mathrm{K}$ ile $32^{\circ} 5^{\prime} 5^{\prime \prime} \mathrm{D}$ 'dur. da kullanılırlar. Eskiden, Doğu Karadeniz Bölümü kırsal evlerinin yakınında kiler amaçlı kullanılan yapay mağaralar vardı. Halen geleneksel Midyat evlerinde olduğu (Uzun ve Kaplan, 2019) gibi Güneydoğu Anadolu Bölgesi'ndeki bazı evlerin altında da kiler amaçlı kullanılan mağaralar bulunmaktadır. Ayrıca, Nevşehir yöresinde patates, soğan, limon, elma ve nar gibi çeşitli tarım ürünlerinin saklanmasında yapay mağaralardan yararlanılmaktadır (Boyraz ve Zeren, 2012; Ege, 2017; Örüng vd., 2016).

Peynir yapımı, gıda muhafazasının en eski yöntemlerinden biridir ve G.Ö. 8000'lerde Mezopotamya'da başladığı kabul edilir (Stark, 2007). Üretilen peynirlerin saklanması ve mikrobiyolojik faaliyetlerle olgunlaştırılması için yüzyıllardan beri mağaralardan yararlanılmaktadır. Nitekim Roquefort (Fransa) ve Gorgonzola (İtalya) gibi Avrupa'da çok bilinen bazı peynir çeşitleri mağaralarda üretilmektedir. Ülkemizde de mağaralarda olgunlaştırılmış peynir çeşitleri vardır. Bunlar arasında "Karaman Divle Obruğu Tulum Peyniri" (Budak vd., 2016; Ozturkoglu-Budak vd., 2016) ve bu çalışmada incelenen "Peynirini Tulum Peyniri" son yıllarda öne çıkmıştır.

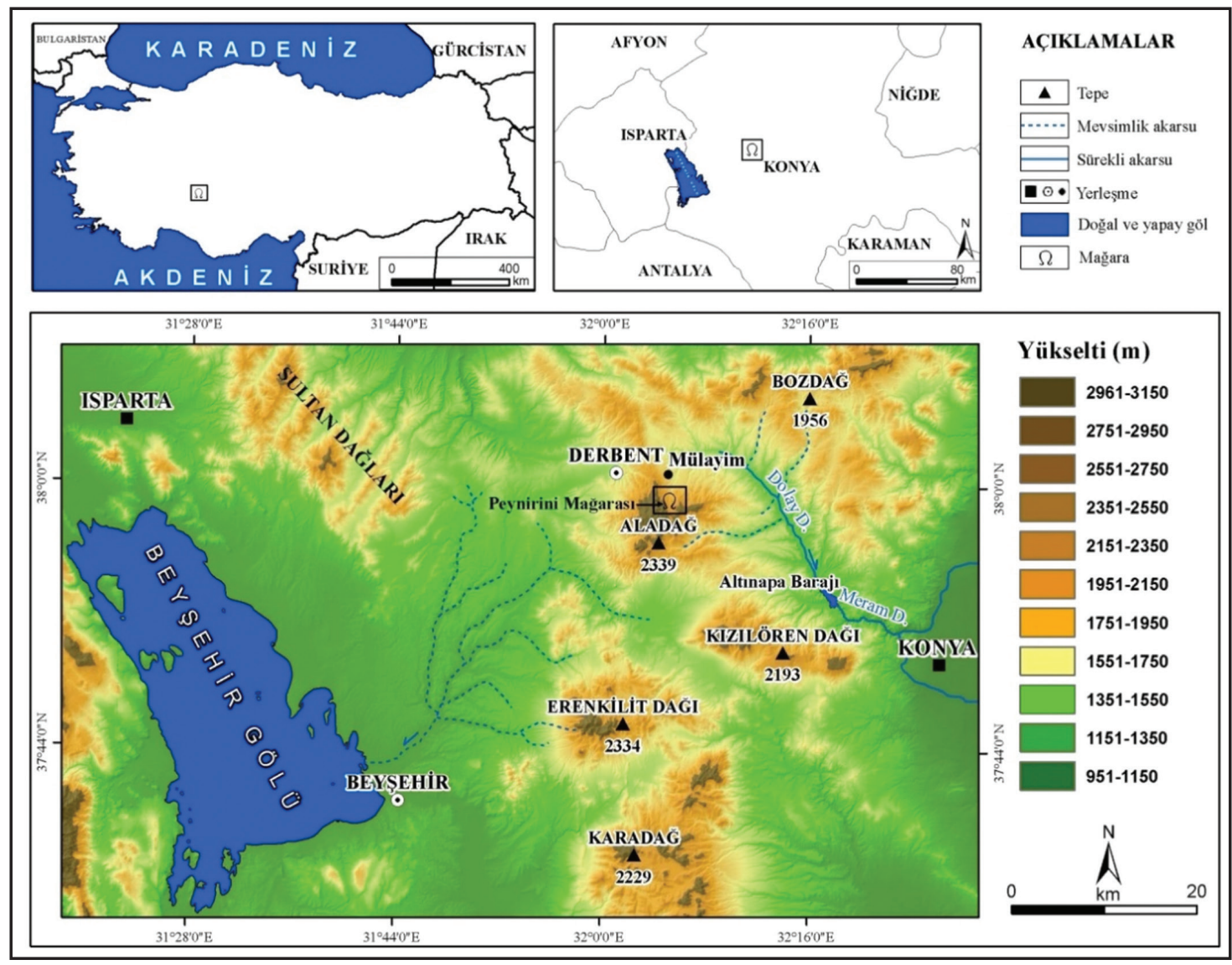

Şekil 1. Araştırma sahasının yer bulduru haritası.

Figure 1. Location map of the research area.

Literatür çalışmaları sırasında, Peynirini Mağarası'nda peynir üretimiyle ilgili ayrıntılı bir çalışmaya rastlanmamıştı. Ancak, mağaranın jeolojik ve jeomorfolojik özelliklerine değinen iki yayımlanmamış araştırma raporu (Güngör vd., 2018; Nazik vd., 2005) ile yerel halkın mağaradan yararlanması konusunda özeti yayımlanmış bir bildiri hazırlanmıştır (Sarı ve Aydemir, 2017).

Mağaralar genellikle serin, nemli ve yıl boyu kararlı bir iklime sahiptir. Bu nedenle de gıda muhafazası ve olgunlaştırılmasın-
Tulum peynirleri tat ve aroma kazanması için hayvan derilerinden yapılan tulumlara veya plastik bidonlara doldurularak mağaralarda olgunlaştırılmaktadır (Sert, 2011). Bu peynirlerle ilgili bazı çalışmalar mağara koşullarının mikrobiyotayı etkilediğini ve peynirlerin konuldukları mağaraya özgü bir tat ve aroma kazandığını göstermiştir (Bonomo and Salzano, 2012; Kan vd., 2010; Kurt vd., 1991; Tekinşen ve Akar, 2017). Peynirini Mağarası tulum peynirleri de kendine özgü tat ve aromasıyla yörede bilinmekte ve beğenilmektedir. 


\section{Veri ve Yöntem}

Bu çalışmada Peynirini Mağarası'nda tulum peyniri üretimi çok yönlü olarak incelenmiştir. Arazi çalışmaları kapsamında mağara morfolojisi ve mağara iklimi ile ilgili ölçümler yapılmış ve gerekli örnekler alınmıştır. Alınan örnekler laboratuvar ortamında mikrobiyolojik analize tabi tutulmuş ve üretilen sayısal veriler istatistiksel yöntemlerle analiz edilmiştir. Ayrıca, Ondokuz Mayıs Üniversitesi Sosyal ve Beşeri Bilimler Etik Kurulu'nun 09.05.2019 tarih ve 2019-189 sayılı kararı ile olgunlaşmış ve olgunlaşmamış peynirlerle ilgili 100 kişiye duyusal anket uygulanmıştır (Fotoğraf 1).

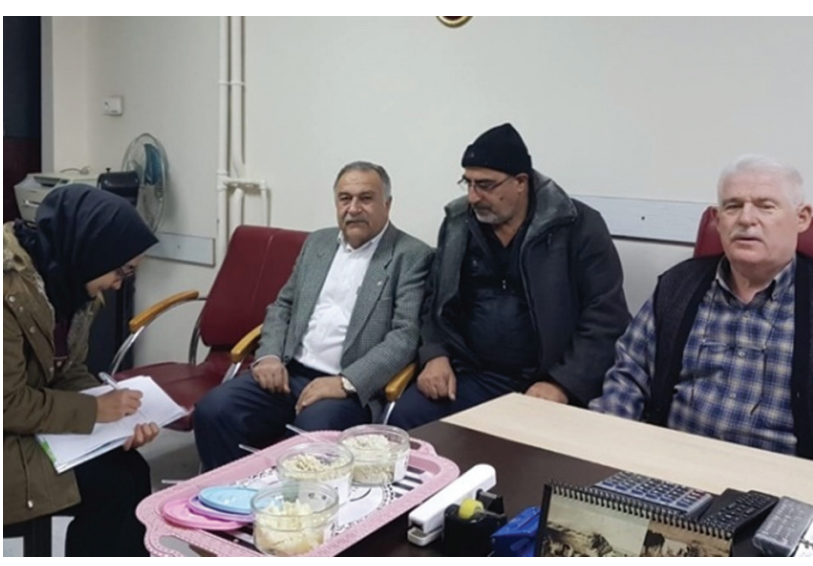

Fotoğraf 1. Duyusal anket çalışmalarından bir görüntü.

Photo 1. A view from sensory questionnaire studies.

Peynirini Mağarası'nın iklim özelliklerini araştırmak için mağara dışına, mağara girişine, Peynir Salonu'na ve Alt Salon'a ölçüm cihazları yerleştirilmiş ve bir yıl boyunca (01.06.2019 - 31.05.2020) otomatik kaydedici cihazlarla günlük sıcaklık ve nem ölçümleri yapılmıştır. Aylık kontrollerimiz sırasında nem ölçüm cihazlarıyla yapılan kayıtlar beklentilerin üzerinde sonuçlar vermiştir. Bunun üzerine farklı model kayıt cihazı kullanılmış, ancak sonuç yine değişmemiştir. Buna rağmen, mağara havasının nem miktarına ihtiyatlı yaklaşılmalı ve sabit olmayan cihazlarla yeniden ölçülmelidir. İlgili literatürde sürekli mağara içinde kalan cihazların üzerindeki yoğunlaşmanın böyle bir sonuca sebep olabileceği belirtilmektedir (Tobin vd., 2013).

Mağara iklimini araştırmak amacıyla 2 adet CEM DT-171 ve 2 adet CEM DT-172 sıcaklık ve nem kayıt cihazları kullanılmıştır. Bu cihazlar Mağara dışına, mağara girişine, Peynir Salonu'na ve Alt Salon'a yerleştirilmiştir. Nem ve sıcaklık ölçümleri eş zamanlı olarak ve 24 saat kayıt sistemine göre yapılmıştır. Kayıt işlemleri, peynir üretim dönemini (1 Haziran 2019 - 31 Aralık 2019) de kapsayacak şekilde bir yıl boyunca devam etmiş ve ölçüm sonuçları SigmaPlot 12.0 yazılımı kullanılarak kıymetlendirilmiştir.

Mikrobiyolojik analiz için, peynir olgunlaşma zaman aralığı dikkate alınarak mağara damlama suyundan $(10 \mathrm{ml})$, mağara taşlarından $\left(100 \mathrm{~cm}^{2}\right)$ ve olgunlaştırılmış peynirlerden (100 gr) örnekler alınmıştrr. Mağara taşlarından sürüntü örneği almak için eküvyon çubuğu ve besiyerli Swab tüpü kullanılmıştır (Fotoğraf 2).

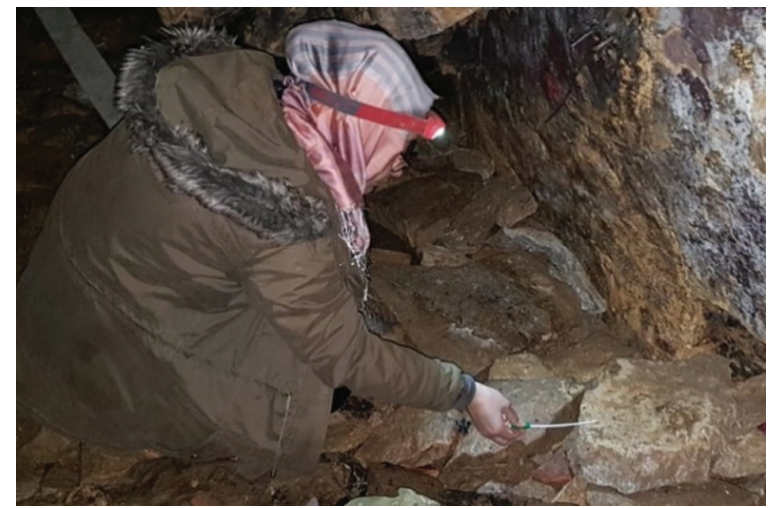

Fotoğraf 2. Mağara içi örnek alma çalışması. Photo 2. Studies to take sample inside cave.

Örneklerdeki toplam aerobik mezofilik bakteri sayımı (TAMB) için Plate Count Agar (PCA), maya küf sayımı için Potatoes Dextrose Agar (PDA), koliform bakteri sayımı için Violet Red Bile Agar (VRBA) ve Staphylococcus bakteri sayımı için de Baird Parker Agar (BPA) yöntemleri kullanılmıştır.

Mağara peynirinin kalite karakterinin ve tercih derecesinin değerlendirilmesi için 100 kişilik panelist gruba duyusal anket uygulanmıştır. Panelist grup, Konya ilinin Selçuklu ve Karatay ilçelerinde yaşayan 25 yaş üstü katılımcılardan rastgele seçilmiştir. Değerlendirmede aynı standartlarda hazırlanan tulum peynirinin, mağarada olgunlaştırılmış ve olgunlaştrılmamış halinin tat ve koku ölçütleri esas alınmıştr. Duyusal analiz form sonuçları için SPSS 18.0 istatistik programı kullanılarak grup karşılaştırması (Paired Samples t Testi) yapılmıştır. Mağara damlama suyundaki ve mağara çeperlerindeki bakterileri sayılarının, tulum peyniri bakteri sayıları üzerindeki etkisi ise regresyon (Simple Linear Regression) ve korelasyon (Pearson Product Moment Correlation Coefficient) analizleri ile incelenmiştir.

\section{Bulgular \\ 3.1.Coğrafi Arka Plan}

Peynirini Mağarası, Konya'nın Derbent ilçesinde, Aladağ'ın (2339 m) kuzeydoğuya bakan yamaçları üzerinde ve Miskinçukuru Deresi'nin sağ sahilinde yer alır. Mağara, yörede geniş bir yayılış gösteren Triyas yaşlı kireçtaşları içerisinde gelişmiştir (MTA, 2020; Nazik vd., 2005). Yöre karasal bir iklime sahiptir. Yazlar sıcak ve kurak, kışlar soğuk ve kar yağışlı geçmektedir. Yıllık ortalama sıcaklık $7.4^{\circ} \mathrm{C}$, yıllık ortalama yağış ise $612.9 \mathrm{~mm}$ 'dir (MGM, 2019). Mağara çevresinin sularını Miskinçukuru Deresi drene etmektedir. Konya kapalı havzasına dâhil olan akarsu yalnızca yağmurlu günlerde su taşımaktadır. Mağara çevresinde esas elemanlarını karaçam (Pinus nigra), saçlı meşe (Quercus cerris) ve katran ardıcı (Juniperus oxycedrus) gibi türlerin oluşturduğu orman bakiyelerine rastlanır. Yöre büyük kısmıyla potansiyel orman sahası içinde yer alır. Ancak yüzyıllardan beri devam eden tahripler nedeniyle ormanlar önemli ölçüde daralmıştır. Yerleşim yerlerine yakın ve uygun eğime sahip ormansız alanlarda tarla ve bahçe tarımı yapılmaktadır. Geri kalan kısımlar genellikle mera olarak değerlendirilmektedir.

Mülayim Mahallesi'nde hayvancılık yaygındır. Bu durum, diğer süt mamulleri yanında peynir üretimini de desteklemiştir. Öte yandan yörede peynirlerin saklanması ve olgunlaştırılması için Peynirini Mağarası'ndan yararlanılmaktadır. Mülayim Mahallesi'nden mağaraya 3 km'lik toprak bir yolla ulaşılır. Mülayim 
Mahallesi'nin Derbent ilçe merkezine uzaklığı 9 km, Konya il merkezine uzaklığı ise 50 km'dir.

\subsection{Mağaranın Jeomorfolojik Özellikleri}

Peynirini Mağarası toplam 187 m galeri uzunluğuna ve 24,5 m derinliğe sahiptir (Nazik vd., 2005). Karstik çözünmeyle oluşan mağara verev yönde gelişmiştir. Mağara içe doğru alçalan bir özellik gösterir. Özel donanımsız girilebilen ilk yarısı "Giriş" bölümü, "Peynir Salonu" ve "Alt Salon"dan oluşur (Şekil 2).

Mağara ağzından Peynir Salonu'na eğimli bir koridorla inilir. Peynir Salonunun tabanı girişten $7 \mathrm{~m}$ aşağıdadır. Bu salonun uzunluğu $21 \mathrm{~m}$, genişliği $11 \mathrm{~m}$ ve tavan yüksekliği 6 m’dir (Şekil 2). Bu salon, peynirlerin olgunlaştırılmak için depolandığı ana bölümdür. Yoğun talep durumlarında giriş koridoruna da peynir konur. Giriş bölümü dış atmosfer şartlarından etkilendiği için, mağara ağzı ağaç dalları ve hasırlarla kapatılır (Fotoğraf 3). Ayrıca, peynirlerin güvenliği için mağara ağzı demir bir kapı ile kapatılmıştır. Olgunlaşma döneminde mağara kapısı kilitli tutulur ve anahtarı da mağara bekçisinde bulunur.

Peynir Salonu'ndan Alt Salon'a dar bir geçitle inilir. Alt Salon'un tabanı girişten $20 \mathrm{~m}$ aşağıdadır. Tavan yüksekliği 1-9 m, genişliği ise 0.65-9 m arasında değişir. Bu salon damlataşı oluşumları bakımından zengindir (Fotoğraf 4 ).

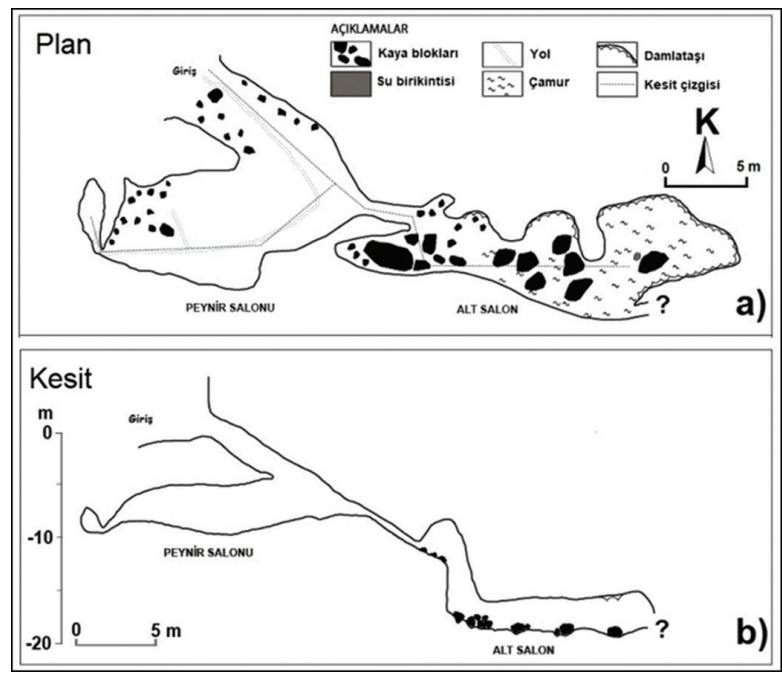

Şekil 2. Peynirini Mağarası'nın donanımsız girilebilen ilk yarısının planı (a) ve boyuna kesiti (b), (Nazik vd., 2005'den yeniden çizildi).

Figure 2. The plan of the first half of the Peynirini Cave (a) and the longitudinal section (b), which can be entered without equipment.

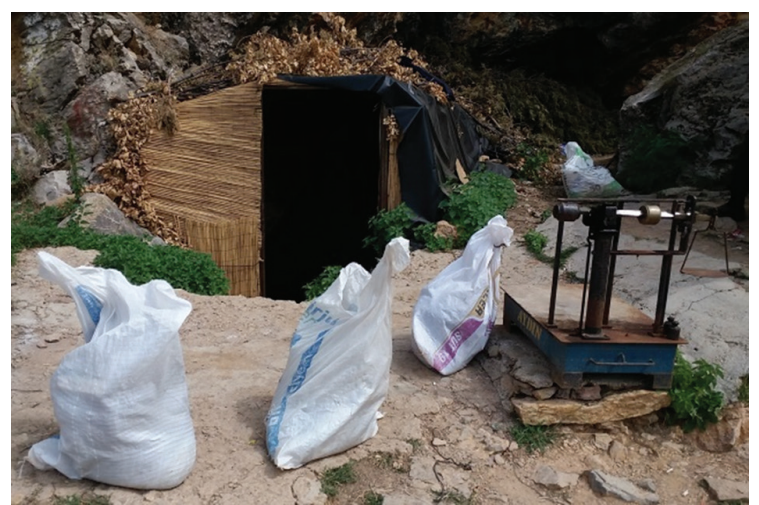

Fotoğraf 3. Mağara girişinin görünüşü. Mağaraya konulacak peynirler tartılarak teslim alınır.

Photo 3. A view of cave entrance. The cheeses to be put into the cave are weighed and received.

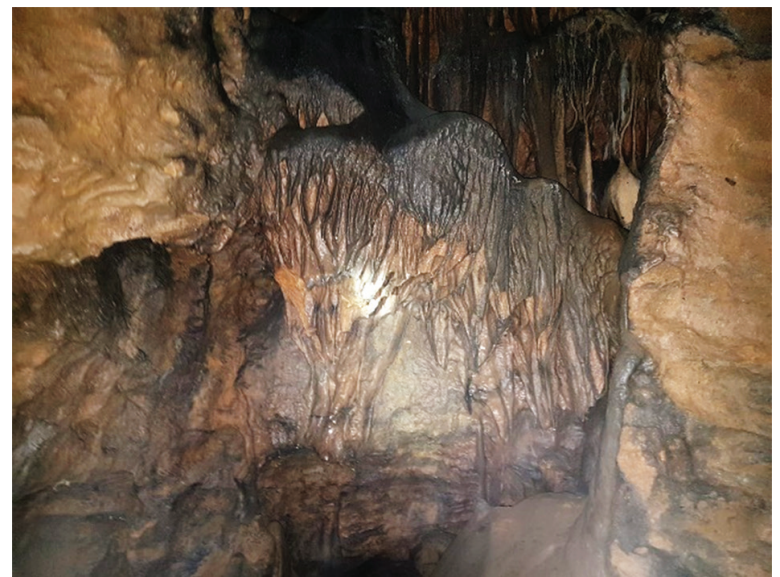

Fotoğraf 4. Alt salonda bulunan akmataşı şekilleri.

Photo 4. Flowstone in the ground hall.

\subsection{Mağaranın İklimi}

Mağaralar genellikle serin, nemli ve yıl boyu kararlı bir iklime sahiptir. Ağız kısımları hariç genellikle karanlık ortamlardır ve dışardaki hava şartlarından fazla etkilenmezler. Gece - gündüz ve yaz - kış arasındaki sıcaklık genlikleri düşüktür (Bekaroğlu ve Yiğitbaşığlu, 2010; Cigna, 2004). Mağara havası, yazın dışarıdaki havadan daha serin, kışın ise daha ılık olur. Bununla birlikte mağaranın büyüklüğü, mağara girişinin tek ya da çok olması, mağara girişlerinin yeri ve genişlikleri vs. de mağara iklimini etkiler. Ayrıca, bu faktörlerle ilişkili olarak dışarıdan mağaraya enerji transferine neden olan hava akımı, yeraltı akarsuları, kalabalık hayvan ve insan hareketleri vs. de mağara iklimini etkiler. Bu nedenle her mağaranın kendine özgü bir iklimi oluşmuştur. Peynirini Mağarası da kendine özgü bir iklime sahiptir.

Mağara iklimi, mağara içindeki damlataşı oluşumu yanında, mağara canlılarının gelişimini ve özellikle de mikrobiyolojik faaliyetleri kontrol eder. Mağara mikrobiyotası ise peynirlerin olgunlaşmasında ve hijyen koşullarının belirlenmesinde etkili olur.

Peynirini Mağarası'nın günlük sıcaklık ve nem miktarları otomatik kayıt yapan cihazlarla eş zamanlı olarak ölçülmüş ve bu veriler kullanılarak yılık sıcaklık ve nem grafikleri çizilmiştir (Şekil 3; Şekil 4). Bu şekillerden de görüleceği üzere, mağara dışında günlük sıcaklık ve nem değerleri ciddi şekilde değişirken, mağara içinde bu iklim elemanlarının yıl boyunca kararlı bir gidişi söz konusudur.

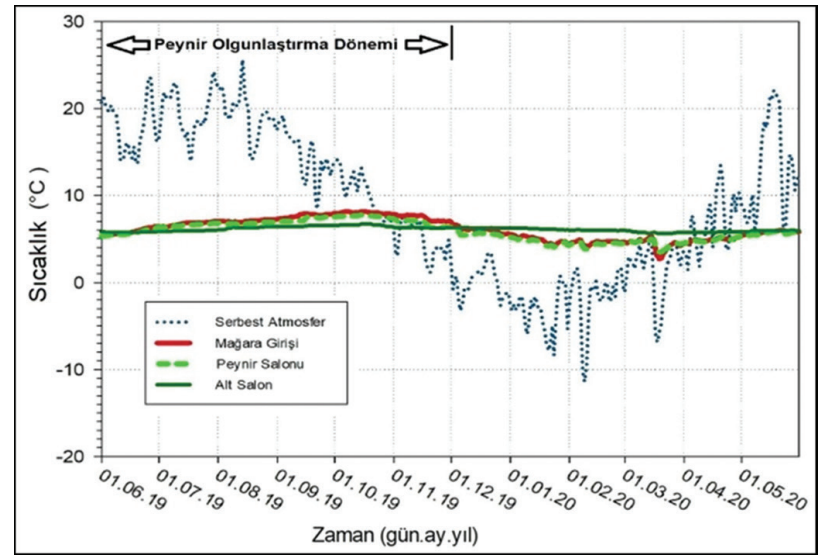

Şekil 3. Peynirini Mağarası'nın yıllık sıcaklık grafiği, 2019-2020.

Figure 3. The annual temperature diagram of Peynirini Cave, 2019-2020. 


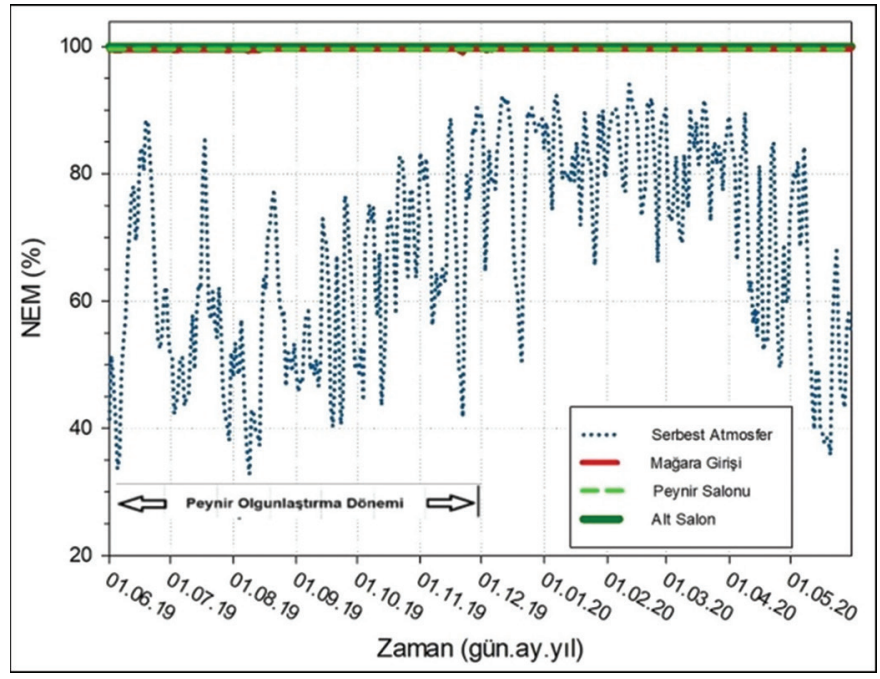

Şekil 4. Peynirini Mağarası'nın yıllık nem grafiği, 2019-2020.

Figure 4. The annual humidity diagram of Peynirini Cave, 2019-2020.

Sahada yaptığımız ölçümlere göre, mağara dışında yıllık ortalama sıcaklık $9^{\circ} \mathrm{C}$, mağara içerisinde (Mağara girişi, Peynir Salonu ve Alt Salon) ise $6{ }^{\circ} \mathrm{C}^{\prime}$ dir (Tablo 1). Buna göre, mağara havası dışarının havasından $3{ }^{\circ} \mathrm{C}$ daha serindir. Buna karşılık, mağara dışında yıllık en yüksek sıcaklık $26^{\circ} \mathrm{C}$ iken, mağara girişinde ve Peynir Salonu'nda $8^{\circ} \mathrm{C}$, Alt Salon'da ise $7{ }^{\circ} \mathrm{C}$ olmuştur. Yıllık en düşük sıcaklık ise, mağara dışında $-11^{\circ} \mathrm{C}$ iken, mağara girişinde $3{ }^{\circ} \mathrm{C}$, Peynir Salonu'nda $4{ }^{\circ} \mathrm{C}$ ve Alt Salon'da $6^{\circ} \mathrm{C}$ olmuştur (Tablo 1). Dolayısıyla ekstrem sıcaklıkların genliği dıştan içe doğru azalır. Nitekim, mağara dışında yıllık sıcaklık farkı $37^{\circ} \mathrm{C}$ 'yi bulurken, mağara girişinde $5{ }^{\circ} \mathrm{C}$, Peynir Salonu'nda $4{ }^{\circ} \mathrm{C}$ ve Alt Salon'da ise sadece $1{ }^{\circ} \mathrm{C}$ olmuştur (Tablo 1 ). Buna göre, mağara havasının sıcaklığı yıl boyunca $8{ }^{\circ} \mathrm{C}^{\prime}$ nin altındadır. Mağara girişi dışarıdaki havadan kısmen etkilenmektedir. Ancak, bu etki mağaranın içine doğru ilerlendikçe azalmakta ve sıfira yaklaşmaktadır (Tablo 1).

Tablo 1. Peynirini Mağarası'nın bir yıllık ortalama ve ekstrem sıcaklık değerleri (01.06.2019 - 31.05.2020).

Table 1. One-year average and extreme temperature values of Peynirini Cave (01.06.2019 - 31.05.2020).

\begin{tabular}{|c|c|c|c|c|c|}
\hline & İklim Elemanı & $\begin{array}{c}\text { Mağara } \\
\text { Dışı }\end{array}$ & $\begin{array}{c}\text { Mağara } \\
\text { Girişi }\end{array}$ & $\begin{array}{l}\text { Peynir } \\
\text { Salonu }\end{array}$ & Alt Salon \\
\hline \multirow{4}{*}{$\begin{array}{l}\frac{0}{0} \\
\frac{\text { 竘 }}{\text { ज }}\end{array}$} & Ort. & 9 & 6 & 6 & 6 \\
\hline & Maks. & 26 & 8 & 8 & 7 \\
\hline & Min. & -11 & 3 & 4 & 6 \\
\hline & Yıllık Fark & 37 & 5 & 4 & 1 \\
\hline \multirow{4}{*}{$\frac{\bar{\varrho}}{\frac{\varepsilon}{2}}$} & Ort. & 68,2 & 99,6 & 99,6 & 100 \\
\hline & Maks. & 94,1 & 99,7 & 99,6 & 100 \\
\hline & Min. & 32,8 & 99,0 & 99,6 & 100 \\
\hline & Yıllık Fark & 61,3 & 0,7 & 0 & 0 \\
\hline
\end{tabular}

Yapılan nem ölçümlerine göre, mağara havası yüksek nem doygunluğa sahiptir ve yıl içinde kararlı bir gidiş söz konusudur (Şekil 4). Buna karşılık mağara dışında nem miktarı daha düşük ve daha kararsızdır. Nitekim, mağara dışında yıllık ortalama nem miktarı \%68,2 iken, mağara girişinde ve Peynir Salonu'nda \%99,6; Alt Salon'da ise \%100 olmuştur. Yıllık ekstrem nem değerleri arasındaki fark da mağara dışında yüksek (\%61,3), mağara içinde ise oldukça düşüktür (Mağara girişinde \%0,7, Peynir Salonu'nda ve Alt Salon'da sıfirdır.).
3.4. Mağara Ortamının ve Tulum Peynirinin Mikrobiyolojik Özellikleri

Mağaranın mikroorganizmaları peynirlerin olgunlaşmasını ve olgunlaşma ortamının hijyenik şartlarını etkiler. Bu nedenle Peynir Salonu'nun duvarlarından damlama suyundan ve olgunlaştrıımış peynirlerden örnekler alınmış ve toplam aerobik mezofilik bakteri (TAMB), toplam maya küf (TMK), toplam koliform ve Staphylococcus sayıları belirlenerek tablo halinde düzenlenmiştir (Tablo 2)

Tablo 2. Mağara damlama suyu, mağara duvarı ve olgun tulum peynirinin mikrobiyolojik özellikleri.

Table 2. Microbiological properties of cave drip water, cave wall and Mature Tulum Cheese.

\begin{tabular}{|l|r|r|r|}
\hline Mikroorganizma & $\begin{array}{c}\text { Damlama Suyu } \\
\text { (log kob/ml) }\end{array}$ & $\begin{array}{c}\text { Kaya Yüzeyi } \\
\text { (log kob/yüzey) }\end{array}$ & $\begin{array}{c}\text { Tulum Peyniri } \\
\text { (log kob/g) }\end{array}$ \\
\hline TAMB & 6.30 & 8.03 & 7.20 \\
\hline$T M K$ & 3.50 & 4.24 & 6.40 \\
\hline Koliform & 1.40 & 5.08 & 1.80 \\
\hline Staphylococcus & 1.20 & 3.20 & 0.85 \\
\hline
\end{tabular}

Tablo 2'de de görüleceği üzere, mağara taşlarının TAMB değeri (8.03 log kob/yüzey), mağara damlama suyundan (6.30 log $\mathrm{kob} / \mathrm{ml}$ ) ve tulum peynirinden (7.20 log kob/gr) daha fazladır. TMK sayısı tulum peynirinde mağara ortamından daha fazladır. Tulum peynirindeki Koliform bakteri ve Staphylococcus sayıları ise mağara ortamındakinden daha azdır (Tablo 2).

Mağara damlama suyu, mağara yüzeyi ve tulum peyniri içindeki bakteri miktarları arasındaki ilişki istatistiksel olarak incelenmiştir. Yapılan analize göre, mağara damlama suyu bakterileri ile tulum peyniri bakterileri arasında çok yüksek pozitif bir ilişki $(r=0,918)$, mağara yüzeyi bakterileri ile tulum peyniri bakterileri arasında ise yüksek pozitif bir ilişki tespit edilmiştir $(r=0,669)$, (Şekil 5).

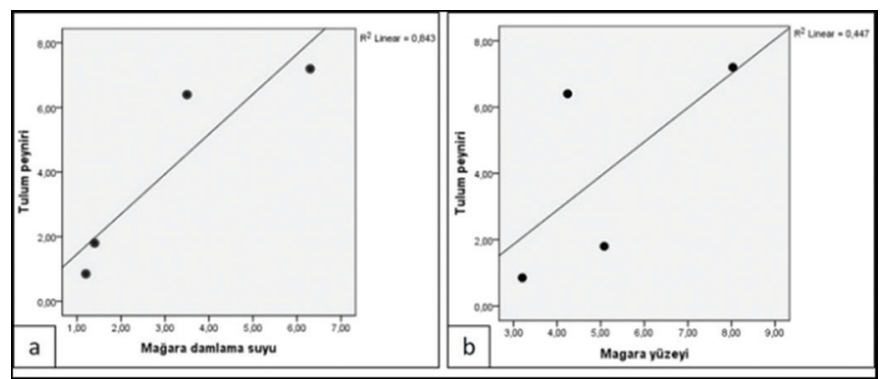

Şekil 5. Mağara damlama suyu bakterileri (a) ve mağara yüzeyi bakterileri (b) ile Tulum peyniri bakterileri arasındaki ilişki.

Figure 5. The relationship between Tulum cheese bacteria and cave drip water bacteria (a) and cave surface bacteria (b).

\subsection{Tulum Peyniri Yapımı}

Peynirini Mağarası tulum peynirleri geleneksel yöntemlerle üretilmektedir. Peynir yapımında genellikle inek sütü, bazen de koyun sütü kullanılmaktadır. Bu tercihin öncelikli sebebi yörede inek yetiştiriciliğinin yaygınlığı olabilir. Ancak, yörede inek sütünden üretilen peynirlerin koyun sütüne göre, daha uzun süre küflenmeden saklanabildiği düşüncesi de yaygındır. Bu hususun ayrıca incelenmesi gerekir.

Sütler sağılıp, süzüldükten sonra makine ile yağı alınır. Henüz soğumamış çiğ sütler mayalanır. Soğumuş sütler ise ılıklaştırılıncaya kadar ısıtıldıktan sonra mayalanır. Mayalama işlemi için 
yaklaşık $1 \mathrm{~kg}$ süte $1 \mathrm{ml}$ 1/18000'lik sıvı peynir mayası kullanılır. Sütler maya katımı sırasında ve katımı takiben birkaç dakika boyunca sürekli karıştırılır. Tencerede mayalanan sütün ağzı kapatılır ve hızlı soğumaması için üzeri bir bezle örtülür. Mayalanmış süt yaklaşık 1 saat sonra pıhtılaşır. Pıhtılaşmış peynirler keselere (bez torba) konarak yüksek bir yere asılır. Suyu süzülen keseler indirilir ve içinde kalan son suların da süzülmesi için üzerlerine ağılık konulur. Peynir kalıplaşttktan ve suyu iyice süzüldükten sonra keseden çıkarılır ve bol su ile yıkanır. "Teleme" olarak bilinen bu taze peynirlere yörede "kalıp peynir" denir.

Kalıp peynirler 2-3 gün tuzda bekletildikten sonra yıkanır ve kuru bir kap içinde el ile ufalanır. Ardından tadına bakılarak tuz ayarlaması yapılır. İsteğe bağlı olarak bazen de içine çörek otu eklenir. Tüm bu işlemlerden sonra, peynirler iyice yıkanıp kurutulmuş keçi derisinden yapılmış tulumlara (Yörede "tuluk" denilmektedir) el ile sıkıca bastırılarak doldurulur. Tulumların ağzı peynir içindeki son suların süzülmesine imkan verecek şekilde dikilir ve ağız kısmı alta gelecek şekilde istiflenir. Bu amaçla 30 - 40 kg'lık plastik bidonlar da kullanılmaktadır. Plastik bidonların kapaklarında da bu amaçla delik açılır ve tepesi üzerine istiflenir. Tulumlara ya da plastik bidonlara doldurulan peynirler olgunlaşması için Mayıs sonu Haziran başlarında mağaraya getirilmekte ve 6 ay (Haziran - Kasım ayları arası) kadar mağarada bekletildikten sonra Kasım sonu ya da Aralık ayı başlarında, kar yolları kapatmadan mağaradan alınıp tüketime sunulmaktadır.

\subsection{Tulum Peynirinin Duyusal Analizi}

Peynirini tulum peynirinin duyusal analizi tat ve koku ölçütleri esas alınarak yapılmıştır. Bu değerlendirmeye ilişkin ortalama sonuçlar Tablo 3'te gösterilmiş, taze peynirle olgun peynir arasında anlamlı bir fark olup olmadığı $p<0,05$ anlam düzeyinde incelenmiştir.

Tablo 3. Peynirini Mağarası Tulum Peyniri'nin duyusal değerlendirme sonuçları. Table 3. Sensory evaluation results of Peynirini Mağarası Tulum Cheese.

\begin{tabular}{|l|r|r|c|}
\hline Özellik & Taze Peynir & Olgun Peynir & P* \\
\hline Tat ve aroma & 6,40 & 7,23 & 0,015 \\
\hline Koku & 6,15 & 7,00 & 0,019 \\
\hline * $<0,05$
\end{tabular}

Tablo 3'te de görüleceği üzere, mağarada olgunlaştırılmış tulum peyniri taze peynire göre tat ve koku bakımından daha fazla beğenilmiştir.

\subsection{Mağaranın Yöre Ekonomisindeki Yeri}

Peynirini Mağarası Derbent Belediyesi tarafindan ihale usulü ile kiralanmakta ve işletmeci mağarada bir bekçi bulundurmaktadır. Bu görevli taze peynirlerin teslim alınması, olgunlaşma döneminde korunması, dönem sonunda sahibine teslim edilmesi ve mağaranın temiz tutulması gibi işlerden sorumludur. Mağara kapısı giriş çıkışlar dışında görevli tarafindan kilitli tutulmaktadır.

Mağarada olgunlaştırılan peynirler kilogram üzerinden ücretlendirilmektedir. Mağaraya konulan peynirlerin miktarı yıldan yıla değişmektedir. Örneğin 2018 yılında mağaraya 43 ton peynir konulmuş iken, bu rakam 2019 yılında 38 tona düşmüştür. Dolayısıyla depolanan peynirden elde edilen gelir de yıldan yıla değişmektedir.

Peynirini Mağarası tulum peynirleri kendine has tadı ve kokusuyla yöre halkı tarafindan tanınmakta ve tercih edilmektedir
Mağarada olgunlaşttrılan peynirlerin önemli bir kısmı üretici aileler tarafindan tüketilmektedir. Ancak, ihtiyaç fazlası ürünler yöredeki semt pazarlarında satılarak aile bütçesine katkı sağlanmaktadır. Son yıllarda bu peynirlerin tanınırlığı artmış, çevre il ve ilçelerden de talepler olmaya başlamıştır.

\section{Sonuçlar ve Öneriler}

Tarih öncesi dönemlerden beri peynirlerin saklanması ve olgunlaştrııması için doğal mağaralardan yararlanılmaktadır. Genellikle orta kuşağın dağlık alanlarında gelişmiş olan kuyu şekilli mağaralar "soğuk hava kapanı" özelliği göstermektedir. Bu mağaraların girişleri üst taraftan olduğu için kışın dışarıdaki soğuk hava mağaraya dolar. Ancak yazın havalar ısınsa da, soğuk hava mağaraya yerleşmiş olduğundan yıl boyu içeride tutuklu kalır. Ülkemizde özellikle Toros dağıık kuşağında "orbuk" diye tanımlanan ve düşey yönde gelişmiş bu tip mağaralar peynir depolama amacıyla kullanılmaktadır (Ege, 2017).

Mağara iklimi mağara içindeki ve depolanan peynirlerdeki mikroorganizmaların türü ve sayısı üzerinde kontrol edici bir etki yapar (Bonomo and Salzano, 2012; Çetin vd., 2006; Gürses vd., 2004; Hutkins, 2008; Northolt and Bullerman, 1982). Peynirini Mağarası'nın yıllık ortalama sıcaklığı $6{ }^{\circ} \mathrm{C}$ ve yıllık ortalama nem miktarı \%99,6'dır. Ayrıca, mağaranın sıcaklık ve nem miktarlarının yıl boyunca ortalamalar düzeyinde kararlı bir gidiş sergilemesi de tulum peynirinin olgunlaştırılması açısından uygunluk göstermektedir.

Mağara iklimi ortamının mikrobiyolojik özelliklerini etkilemekte ve özellikle de yüksek nem mikrobiyal gelişimi desteklemektedir (Çetin vd., 2006). Mağara ortamının mikrobiyolojik özellikleri ise tulum peynirlerini etkilemektedir. Nitekim yapılan analizlerde mağara ortamının mikrobiyal özellikleri ile tulum peynirleri arasında yüksek ve çok yüksek pozitif bir ilişki bulunmuştur.

Sağlık açısından zararlı olan Staphylococcus (Küçükçetin ve Milci, 2008; Ös ve Karaboz, 2005) ve Koliform bakteriler (Alemdar vd., 2009; Ateş, Özkızılcık vd., 2011) mağara ortamında bulunmakta ve tulum peynirlerine bulaşabilmektedir. Bu nedenle, mağaradan tulum peynirlerinin alınmasından sonra ortamın çok dikkatli bir şekilde temizlenmesi gerekmektedir. Öte yandan, tulum peyniri içindeki Staphylococcus (0.85) ve Koliform (1.80) sayıları, Türk Gıda Kodeksi Mikrobiyolojik Kriterler Tebliği (2011)'e göre kabul edilebilir sınırlar içindedir $\left(<10^{3}\right)$.

Mağara ortamındaki maya küf sayıları da tulum peynirlerini etkilemektedir. Küfler baskın karakterlidir ve dinamik bir yapıya sahiptir. Bu nedenle tulum peynirlerindeki küf aktivitesi Koliform ve Staphylococcus gibi zararlı bakterilerin üremesini sınırlandırmakta ya da yok olmasına sebep olmaktadır (Sert, 2020).

Duyusal değerlendirme sonuçlarına göre mağarada olgunlaştırılmış peynirlerin tadı ve kokusu, benzer şartlarda üretilmiş taze peynire göre daha çok beğenilmiştir.

Mağaradan daha etkin bir şekilde yararlanabilmek için aşağıdaki hususlara dikkat edilmesi önerilmektedir:

- Mağara içinde peynirlerin düzenli bir şekilde istiflenebilmesi ve depolanma kapasitesinin artırılabilmesi için raf sistemi kurulmalıdır. Bu amaçla paslanmaz çelik ya da plastik malzeme kullanılabilir. Demir malzeme kısa zamanda paslandığından, ahşap malzeme ise mikroorganizmaların barınması için uygun ortam oluşturduğundan önerilmemektedir. 
- Mağara tabanı eğimli ve düzensiz olduğundan giriş çıkışlar tehlikeli olmaktadır. Bu nedenle mağara içine anakaya ile uyumlu, kalker, mermer, traverten ya da tufa kaplı merdiven basamakları yapılmalıdır.

- Mağaranın aydınlatılması da çözülmesi gereken bir diğer sorundur. Ancak aydınlatma çalışmaları yapılırken mağara ekosistemine zarar verilmemeli ve Isı yaymayan elektrikli aydınlatma yapılmalıdır.

- Peynirlerin tat, koku, görünüş ve dokusunu etkileyen küf ve bakterilerin aktivitesi için peynir üretiminin tüm evrelerinde ayrıntılı mikrobiyolojik analizler yapılmalıdır.

- Tulum peyniri üretimi, tüm üretim basamaklarında standart ve kontrol edilebilir şartlar altında gerçekleştirilmelidir.

- Peynir üretiminin artırılması, peynirlerin tanıtılması ve marka değerinin korunması için, coğrafi işaret alma çalışmaları başlatilmalıdır.

- $\quad$ Aladağ Kayak Merkezi'nde bir stand açılmalı, ziyaretçilere hem tanıtım hem de satış yapılmalıdır.

\section{Katkı Belirtme}

Bu çalışma Ondokuz Mayıs Üniversitesi tarafindan desteklenen PYO.FEN.1904.18.030 numaralı proje kapsamında hazırlanmıştır.

\section{Etik Kurul İzin Belgesi}

T.C. Ondokuz Mayıs Üniversitesi Sosyal ve Beşeri Bilimler Etik Kurulu'nun 09.05.2019 tarih ve 2019-189 sayılı kararı.

\section{Kaynakça}

Alemdar, S., Kahraman, T., Ağaoğlu, S. ve Alişarlı, M. (2009). Bitlis ili içme sularının bazı mikrobiyolojik ve fizikokimyasal özellikleri. Ekoloji Dergisi 19(73): 29-38.

Ateş, M., Özkızılcık, A. and Tabakoğlu, C. (2011). Microbiological analysis of stuffed mussels sold in the streets. Indian Journal of Microbiology 51(3): 350-354.

Bekaroğlu, E. ve Yiğitbaşığlu, H. (2010). Karaca Mağarası'ndaki (Gümüşhane) bir yıllık sıcaklık ölçüm sonuçlarının değerlendirilmesi. Ankara Üniversitesi Çevrebilimleri Dergisi 2(1): 1-12.

Bonomo, M. G. and Salzano, G. (2012). Microbial diversity and dynamics of Pecorino di Filiano PDO, a traditional cheese of Basilicata region (Southern Italy). International Journal of Dairy Technology 65(4): 531-541.

Boyraz, Z. ve Zeren, C. (2012). Kavak ve Ortahisar (Nevşehir) kasabalarındaki doğal soğutmalı yeraltı depolarına coğrafi bir bakış. Journal of World of Turks 4(1): 23-40.

Budak, S. O., Figge, M. J., Houbraken, J., and de Vries, R. P. (2016). The diversity and evolution of microbiota in traditional Turkish Divle Cave cheese during ripening. International Dairy Journal 58: 50-53.

Cigna, A. (2004). Climate of Caves. Encyclopedia of Caves and Karst Science: 467-475, London: Taylor \& Francis.

Çetin, B., Gürses, M. ve Şengül, M. (2006). Nispi Nem Değişiminin Tulum Peynirinin Bazı Mikrobiyolojik Özellikleri Üzerine Etkisi. Türkiye 9. Gıda Kongresi, Bolu.

Ege, I. (2017). Karstik Şekillerin Farklı Bir Kullanımı: "Orbuklar". International Periodical for the Languages, Literature and History of Turkish or Turkic 12(29): 201-224.

Gillieson, D. (1998). Caves: Processes, Development and Management. Oxford: Blackwell.

Güngör, Y., Çiftçi, Y., Kayacılar, C. ve Azaz, D. (2018). Peynirini Mağarası'nın (Derbent-Konya) Tabiat Varlığı Olarak Tesciline Yönelik Araştırma Raporu. Ankara: T.C. Çevre ve Şehircilik Bakanlığı.

Gürses, M., Erdogan, A. ve Sert, S. (2004). Farkli Depolama Sartlarinin Aspergillus parasiticus NRRL 2999 Küf Susu ile Asilanan Tulum Peynirinde Aflatoksin Qlusumu Üzerine Etkisi. Turkish Journal of Veterinary \& Animal Sciences 28(1).
Hutkins, R. W. (2008). Microbiology and Technology of Fermented Foods. Oxford: Blackwell.

Kan, M., Gülçubuk, B., Kan, A. ve Küçükçongar, M. (2010). Coğrafi işaret olarak Karaman Divle Tulum Peyniri. Karamanoğlu Mehmetbey Üniversitesi Sosyal ve Ekonomik Araşttrmalar Dergisi 2: 15-23.

Kurt, A., Çakmakçı, S., Çağlar, A. ve Akyüz, N. (1991). Erzincan Tulum (Şavak) Peynirinin Yapılışı, Duyusal, Fiziksel ve Kimyasal Özellikleri Üzerinde Bir Araştrrma. GIDA 16(5): 295-302.

Küçükçetin, A. ve Milci, S. (2008). Staphylococcus Aureus İle Kontamine Olan Peynirlerden Kaynaklanan Gıda Zehirlenmeleri. GIDA 33(3): 129-135.

MGM (Meteoroloji Genel Müdürlüğü) (2019). Meteorolojik Veri Bilgi Sunum ve Satış Sistemi. <https://mevbis.mgm.gov.tr/mevbis/ui/ index.html\#/Workspace>. Son erişim 14 Eylül 2020.

MTA (Maden Tetkik ve Arama Genel Müdürlüğü) (2020). Yerbilimleri Harita ve Çizim editörü. <http://yerbilimleri.mta.gov.tr/anasayfa.aspx>. Son erişim 19 Eylül 2020.

Nazik, L. ve Poyraz, M. (2017). Türkiye Karst Jeomorfolojisi Genelini Karakterize Eden Bir Bölge: Orta Anadolu Platoları Karst Kuşağı. Türk Coğrafya Dergisi 68: 43-56.

Nazik, L., Tuncer, K., Savaş, F., İnan, H., Kahraman, I. ve Özel, E. (2005). Mülayim (Peynirini) Mağarası Araştırma Raporu. Ankara: Maden Tetkik ve Arama Genel Müdürlüğü.

Northolt, M. D. and Bullerman, L. B. (1982). Prevention of Mold Growth and Toxin Production Through Control of Environmental Conditions. Journal of Food Protection 45(6): 519-526.

Örüng, I., Karaman, S. ve Şirin, Ü. (2016). Nevşehir Yöresindeki Doğal Depoların Modern Depolarla Karşılaştıılması. Nevşehir Bilim ve Teknoloji Dergisi 5: 9-18.

Ös, F. B. ve Karaboz, İ. (2005). İzmir'de Piyasada Açıkta Satışa Sunulan Bazı Gıdaların Staphylococcus Aureus ve Enterotoksinleri Bakımından İncelenmesi. Orlab On-Line Mikrobiyoloji Dergisi 3(6): 6-9.

Ozturkoglu-Budak, S., Gursoy, A., Aykas, D., Koçak, C., Dönmez, S., De Vries, R., and Bron, P. (2016). Volatile Compound Profiling of Turkish Divle Cave Cheese During Production and Ripening. Journal of Dairy Science 99: 5120-5131.

Sarı, C. ve Aydemir, M. (2017). Mağaraların Kırsal Ekonomiye Katkısına Bir Örnek: Mülayim (Peynirini) Mağarası. Türk Coğrafya Kurumu 75. Yıl Uluslararası Kongresi Bildiriler Kitabı 9: 378, Ankara.

Sert, D. (2011). Geleneksel yöntemle üretilen tulum peynirlerinde kullanılan sütün orijinine bağlı olarak olgunlaşma esnasında meydana gelen bazı değişmelerin belirlenmesi. (Doktora), Selçuk Üniversitesi, Konya.

Sert, D. (2020). Küfün, Peynir Mikroorganizmaları Üzerindeki Etkisi. Sözlü Kaynak.

Stark, J. (2007). Cheese and Fermented Sausages. Food Mycology: 333-346, Boca Raton: Taylor \& Francis.

Tekinşen, K. K. ve Akar, D. (2017). Erzincan Tulum Peyniri. Atatürk Üniversitesi Veteriner Bilimleri Dergisi 12(2): 218-226.

TGK (Türk Gıda Kodeksi) (2011). Mikrobiyolojik Kriterler Yönetmeliği. TC. Resmi Gazete.

Tobin, B. W., Hutchins, B. T. and Schwartz, B. F. (2013). Spatial and Temporal Changes in Invertebrate Assemblage Structure from The Entrance to Deep-Cave Zone of A Temperate Marble Cave. International Journal of Speleology 42(3): 4.

Uzun, A. (1995). Tekkeköy'de (Samsun) Mağara-Kale Yerleşmeleri. Doğu Coğrafya Dergisi 1(1).

Uzun, A. ve Kaplan, í. (2019). Yerel Coğrafi Şartların Geleneksel Midyat Evlerine Etkisi, Mardin/ Türkiye. Uluslararası Mardin Artuklu Multıdisipliner Çalışmalar Kongresi. Sosyal Bilimler Tam Metin Kitabı: 70-85, Mardin.

Uzun, A. ve Zeybek, H. I. (1996). Akçakale Mağarası (Gümüşhane). Türk Coğrafya Dergisi 31: 39-53.

Zeybek, H. İ. (2001). Bahçebaşı Mağarası (Turhal-Tokat). Doğu Coğrafya Dergisi 7(6). 